\title{
Ear diseases and factors associated with ear infections among the elderly attending hospital in Arar city, Northern Saudi Arabia
}

\author{
Naif Gharbi Alenezi ${ }^{1}$, Abdulmajeed Ahmed Alenazi ${ }^{1}$, Yahia Abdelgawad Elsayed Elboraei ${ }^{3}$, Abdulrhman \\ Ahmed Alenazi ${ }^{2}$, Tariq Hulayyil Alanazi ${ }^{2}$, Anwar Khalid Alruwaili ${ }^{1}$, Abdulrahman Sulaiman Alanazi ${ }^{2}$, Bader \\ Khalid Alruwaili ${ }^{1}$, Abdulelah Farhan Alanazi ${ }^{2}$ \\ ${ }^{1}$ Intern, Faculty of Medicine, Northern Border University Arar, Kingdom of Saudi Arabia
${ }^{2}$ Faculty of Medicine, Northern Border University Arar, Kingdom of Saudi Arabia
${ }^{3}$ MBCh, MSc and ENT Board at Northern Border University Arar, Kingdom of Saudi Arabia
}

Type of article: Original

\begin{abstract}
Background: Changes in the anatomical structures and function of the ear can result in ear diseases, and may affect all age groups including the elderly as a result of aging

Objective: To identify the frequency and types of ear diseases among the elderly attending Abdullah bin AbdulAziz bin Musa'ed Al Saud hospital, Arar city, in the Northern Province of KSA, and factors associated with ear infections among them.

Methods: This cross-sectional hospital based study conducted from December 2016 through May 2017 included 138 elderly participants. A questionnaire was designed for collecting data about socio-demographic variables, the frequency and types of ear diseases among participants, and factors associated with ear infections among them. Data were analyzed by SPSS version 15, using descriptive statistics and Chi-Square test.

Results: Findings showed that $49.3 \%$ of the participants were suffering from ear disease. Hearing impairment was detected in $37 \%$ of the elderly people studied. In addition, $9.4 \%$ and $2.9 \%$ of the participants suffered from otitis media and otitis interna, respectively. None of the studied factors had a significant effect on the development and pattern of ear infection among the studied population.

Conclusion: Ear diseases were found among the participants with variable rates. More than one third of respondents suffered from hearing impairment. Ear infections were detected in lower rates. Although these problems are not life threating, they negatively impact the quality of life, and measures are needed for prevention and control.
\end{abstract}

Keywords: Ear; Infection; Risk factors

\section{Introduction}

The ear has a complex structure concerned with maintenance of equilibrium as well as hearing. An abnormality or disruption in the anatomical structures and function of the ear can result in ear diseases and may affect all the age groups including the elderly, as a result of aging $(1,2)$. Aging is a natural process that affects all human beings (2), and different body systems are affected by the aging process at different rates (3). It affects all the organs of the body including the ear (4). As age increases, there is degeneration of the tissues which results in increased susceptibility to diseases of the ear such as diminished hearing, impacted wax, chronic suppurative otitis media (1). Age related changes that affect the ears are commonly not life threatening when compared to age related changes and medical diseases that affect the respiratory and cardiovascular systems of the body $(1,4)$. Among the common ear diseases in the elderly is hearing impairment (5). Age related hearing loss may be defined as mid to late adult onset, bilateral, progressive sensorineural hearing loss, after exclusion of any underlying causes. It excludes hearing loss caused by primary factors including loud noise exposure, underlying medical conditions intrinsic ear disease, head injury and drug toxicity (6). Ear infections e.g. otitis media, are considered among the common ear diseases

\section{Corresponding author:}

Naif Gharbi Alenezi, Faculty of Medicine, Northern Border University Arar, Kingdom of Saudi Arabia. Tel: +966558988289, Email: drgharbi1@gmail.com Received: June 19, 2017, Accepted: July 23, 2017, Published: September 2017 iThenticate screening: July 23, 2017, English editing: August 14, 2017, Quality control: August 18, 2017 (C) 2017 The Authors. This is an open access article under the terms of the Creative Commons Attribution-NonCommercialNoDerivs License, which permits use and distribution in any medium, provided the original work is properly cited, the use is non-commercial and no modifications or adaptations are made. 
which are higher in developing countries, especially among low socioeconomic society due to malnutrition, overcrowding, poor hygiene, inadequate health care and recurrent upper respiratory tract infection (7). A variety of factors may be associated with and predisposed to suppurative ear infections including gender, low socioeconomic status, overcrowding, unawareness about the disease, living in a slum area, poor hygiene, bathing in pond/river water, smoking, and foreign bodies in the ear (8). However, the effects of various host and environmental factors have not been well defined (9). Diseases of other systems were reported to be associated with the onset of ear disorders. They may act as important risk factors for the onset of ear problems such as hearing impairment $(10,11)$. The resulting disability caused by ear diseases may not be life threatening, but it has deleterious effects on the patient's quality of life and increases the economic burden on the family (2). So, this study was conducted to identify the frequency and types of ear diseases among the elderly attending Abdullah bin Abdul-Aziz bin Musa'ed Al Saud hospital, Arar city, in the Northern Province of the Kingdom of Saudi Arabia, and factors associated with ear infections among them.

\section{Material and Methods}

\subsection{Study design and participants}

The current study was a cross-sectional hospital based study conducted in Abdullah bin Abdul-Aziz bin Musa'ed Al Saud hospital, Arar city in the Northern Province of the Kingdom of Saudi Arabia. The Abdullah bin Abdul-Aziz bin Musa'ed Al Saud hospital was reviewed for a period of six months (from December 2016 through May 2017). All elderly (60 years old or more) patients referred to or admitted to the hospital, and agreed to participate in the study, were included in the current study. They were subjected to an ear examination to detect any ear diseases among them. Exclusion criteria included patients who refused to participate in the study.

\subsection{Data Collection Method}

A questionnaire was designed to obtain data about the frequency and types of ear diseases among the elderly attending the hospital and factors associated with ear infections among them. Data was collected through face to face interviewing with patients included in the study, and reviewing the results of their ear examination to determine their diagnosis. The questionnaire included questions about age, sex, educational level, marital status of participants and their smoking status. In addition, the questionnaire included inquiries about presence of chronic diseases such as diabetes and hypertension.

\subsection{Ethical consideration}

This study was reviewed and approved by the Research Ethics Committee of the Faculty of Medicine, Northern Border University. Participants were informed that participation is completely voluntary, and a written consent was obtained from each participant before being subjected to the questionnaire and after discussing the objective with the participants. The questionnaires used in data collection were anonymous and all questionnaires were kept safe and confidentiality of data was assured.

\subsection{The statistical analysis}

The statistical analysis was carried out using SPSS software for Windows (version 15.0). Sample characteristics were summarized as numbers and percentages for categorical variables. Chi-Square test was used for comparing qualitative variables. A 5\% level was chosen as a level of statistical significance in all statistical tests used in the study.

\section{Results}

The current study included 183 elderly participants referred to or admitted to the hospital during the study period, who had agreed to participate in the study. Approximately two thirds of the participants $(65.2 \%)$ were between 60 and 70 years of age, $26.1 \%$ were between 70 and 80 years of age, and only $8.7 \%$ were $\geq 80$ years old. There were more females than males $(52.2 \%$ vs. $47.8 \%)$. Concerning the educational status of the studied elderly, $48.6 \%$ were illiterate, $19.6 \%$ had primary education and those with university education represented $15.9 \%$ of the participants. Regarding marital status, $62.3 \%$ of the respondents were married, one third of them (33.3\%) were widows, $2.2 \%$ were divorced and $2.2 \%$ were single. More than two thirds of the respondents $(68.8 \%)$ were nonsmokers and more than one fifth (23.9\%) of them were ex-smokers while only 7.2\% were current smokers at the time of the study. As regards chronic diseases among the studied population, $45.7 \%$ were hypertensive and $37 \%$ were diabetic (Table 1). Regarding the frequency of ear diseases among the studied population, ear diseases were detected in $49.3 \%$ of the studied elderly and $50.7 \%$ of them were disease free. Table 2 shows different types of ear diseases among the studied population. As shown by the illustrated data, $37 \%$ of the participants had diminished hearing, $9.4 \%$ had otitis 
media, and $2.9 \%$ had otitis interna. On the other hand, $50.7 \%$ of the studied population had no ear problems. Regarding the relationship between sociodemographic variables, smoking status and chronic diseases and the detected ear infection, the studied elderly between 60 and 70 years of age constituted the majority of otitis media patients $(84.6 \%)$, otitis interna patients $(100 \%)$ and disease-free participants $(62 \%)$ with no significant difference $(\mathrm{p}=0.27$ ) (Table 3). Females represented $30.8 \%$ of otitis media cases, $75 \%$ of otitis interna cases and $53.7 \%$ of disease-free participants compared to males who constituted $69.2 \%$ of otitis media cases, $25 \%$ of otitis interna cases and $46.3 \%$ of disease-free participants and these differences were insignificant $(\mathrm{p}=0.188$ ). Marital status was not significantly associated with ear infection among the studied population $(\mathrm{p}=0.305)$. Furthermore, most of the otitis media patients $(61.5 \%)$, and otitis interna patients $(75 \%)$ were non-smokers while none of the affected patients were smokers, with no significant association between smoking and ear infection $(\mathrm{p}=0.589)$. None of the studied chronic diseases were significantly associated with ear infections among the studied population where more than $60 \%$ of otitis media patients and half of otitis interna were neither hypertensive nor diabetic, and this difference was statistically nonsignificant.

Table 1. Distribution of the studied elderly population according to sociodemographic variables, smoking status, and comorbidities in, Arar, 2017

\begin{tabular}{|l|l|l|l|}
\hline Variable & $\mathrm{n}$ (total=138) & $\%$ \\
\hline Age group (years) & $60-70$ & 90 & 65.2 \\
\cline { 2 - 4 } & $70-80$ & 36 & 26.1 \\
\cline { 2 - 4 } & $>80$ & 12 & 8.7 \\
\hline \multirow{4}{*}{ Sex } & Female & 72 & 52.2 \\
\cline { 2 - 4 } & Male & 66 & 47.8 \\
\hline \multirow{5}{*}{ Educational status } & Illiterate & 67 & 48.6 \\
\cline { 2 - 4 } & Primary & 27 & 19.6 \\
\cline { 2 - 4 } & Preparatory & 11 & 8.0 \\
\hline & Secondary & 11 & 8.0 \\
\cline { 2 - 4 } & University & 22 & 15.9 \\
\hline \multirow{5}{*}{ Smoking } & Widow & 46 & 33.3 \\
\cline { 2 - 4 } & Married & 86 & 62.3 \\
\cline { 2 - 4 } & Single and/or divorced & 6 & 6.4 \\
\hline Chronic diseases & Non-smoker & 95 & 7.2 \\
\cline { 2 - 4 } & Smoker & 10 & 23.9 \\
\cline { 2 - 4 } & Ex-smoker & 33 & 37.0 \\
\cline { 2 - 4 } & Hypertension & 63 & \\
\cline { 2 - 4 } & DM & 51 & \\
\hline
\end{tabular}

Table 2. Ear diseases among the studied elderly population, Arar, 2017

\begin{tabular}{|l|l|l|}
\hline Ear diseases & $\mathrm{n}$ & $\%$ \\
\hline Otitis Media & 13 & 9.4 \\
\hline Otitis Interna & 4 & 2.9 \\
\hline Diminished hearing & 51 & 37.0 \\
\hline No ear diseases & 70 & 50.7 \\
\hline Total & 138 & 100.0 \\
\hline
\end{tabular}

Table 3. Relationship between otitis media and interna and sex, age group, D.M, smoking, obesity and hypertension among the studied elderly population, Arar, 2017

\begin{tabular}{|c|c|c|c|c|c|c|c|}
\hline \multirow{2}{*}{\multicolumn{2}{|c|}{ Variables }} & \multicolumn{3}{|c|}{ Otitis media and interna, $\mathrm{n}(\%)$} & & \multirow{2}{*}{$\begin{array}{l}\text { Chi- } \\
\text { Square }\end{array}$} & \multirow{2}{*}{$\begin{array}{l}\mathrm{p}- \\
\text { value }\end{array}$} \\
\hline & & Otitis media & Otitis interna & No & & & \\
\hline \multirow[t]{3}{*}{ Age group } & $60-$ & $11(84.6 \%)$ & $4(100.0 \%)$ & $75(62.0 \%)$ & $90(65.2 \%)$ & \multirow[t]{3}{*}{5.17} & \multirow[t]{3}{*}{0.27} \\
\hline & $70-$ & $2(15.4 \%)$ & $0(0.0 \%)$ & $34(28.1 \%)$ & $36(26.1 \%)$ & & \\
\hline & $80+$ & $0(0.0 \%)$ & $0(0.0 \%)$ & $12(9.9 \%)$ & $12(8.7 \%)$ & & \\
\hline \multirow[t]{2}{*}{ Sex } & Female & $4(30.8 \%)$ & $3(75.0 \%)$ & $65(53.7 \%)$ & $72(52.2 \%)$ & \multirow[t]{2}{*}{3.338} & \multirow[t]{2}{*}{0.188} \\
\hline & Male & $9(69.2 \%)$ & $1(25.0 \%)$ & $56(46.3 \%)$ & $66(47.8 \%)$ & & \\
\hline \multirow[t]{4}{*}{ Marital status } & Widow & $2(15.4 \%)$ & $3(75.0 \%)$ & $41(33.9 \%)$ & $46(33.3 \%)$ & \multirow[t]{4}{*}{7.17} & \multirow[t]{4}{*}{0.305} \\
\hline & Single & $1(7.7 \%)$ & $0(0.0 \%)$ & $2(1.7 \%)$ & $3(2.2 \%)$ & & \\
\hline & Married & $10(76.9 \%)$ & $1(25.0 \%)$ & $75(62.0 \%)$ & $86(62.3 \%)$ & & \\
\hline & Divorced & $0(0.0 \%)$ & $0(0.0 \%)$ & $3(2.5 \%)$ & $3(2.2 \%)$ & & \\
\hline
\end{tabular}




\begin{tabular}{|c|c|c|c|c|c|c|c|}
\hline \multirow{5}{*}{$\begin{array}{l}\text { Educational } \\
\text { level }\end{array}$} & Illiterate & $6(46.2 \%)$ & $2(50.0 \%)$ & $59(48.8 \%)$ & $67(48.6 \%)$ & \multirow[t]{5}{*}{ NA } & \multirow[t]{5}{*}{$\mathrm{NA}^{*}$} \\
\hline & Primary & $0(0.0 \%)$ & $2(50.0 \%)$ & $25(20.7 \%)$ & $27(19.6 \%)$ & & \\
\hline & Secondary & $5(38.5 \%)$ & $0(0.0 \%)$ & $6(5.0 \%)$ & $11(8.0 \%)$ & & \\
\hline & University & $2(15.4 \%)$ & $0(0.0 \%)$ & $20(16.5 \%)$ & $22(15.9 \%)$ & & \\
\hline & Preparatory & $0(0.0 \%)$ & $0(0.0 \%)$ & $11(9.1 \%)$ & $11(8.0 \%)$ & & \\
\hline \multirow[t]{3}{*}{ Smoking } & Non-smoker & $8(61.5 \%)$ & $3(75.0 \%)$ & $84(69.4 \%)$ & $95(68.8 \%)$ & \multirow[t]{3}{*}{2.816} & \multirow[t]{3}{*}{0.589} \\
\hline & Smoker & $0(0.0 \%)$ & $0(0.0 \%)$ & $10(8.3 \%)$ & $10(7.2 \%)$ & & \\
\hline & Ex-smoker & $5(38.5 \%)$ & $1(25.0 \%)$ & $27(22.3 \%)$ & $33(23.9 \%)$ & & \\
\hline \multirow[t]{2}{*}{ Hypertensive } & Yes & $4(30.8 \%)$ & $2(50.0 \%)$ & $57(47.1 \%)$ & $63(45.7 \%)$ & \multirow[t]{2}{*}{1.29} & \multirow[t]{2}{*}{0.52} \\
\hline & No & $9(69.2 \%)$ & $2(50.0 \%)$ & $64(52.9 \%)$ & $75(54.3 \%)$ & & \\
\hline \multirow{2}{*}{$\begin{array}{l}\text { Diabetes } \\
\text { Mellitus }\end{array}$} & Diabetic & $5(38.5 \%)$ & $2(50.0 \%)$ & $44(36.4 \%)$ & $51(37.0 \%)$ & \multirow[t]{2}{*}{0.323} & \multirow[t]{2}{*}{0.85} \\
\hline & Non-diabetic & $8(61.5 \%)$ & $2(50.0 \%)$ & $77(63.6 \%)$ & $87(63.0 \%)$ & & \\
\hline
\end{tabular}

* Not applicable

\section{Discussion}

The aging process impacts all the organs of the body, including the ear (the external, the middle and the inner ear) and the elderly are more prone to different types of ear diseases (1). The current study revealed that $49.3 \%$ of the studied elderly had ear diseases and $50.7 \%$ of them were disease-free. These findings are higher than the results of (12), who found that ear diseases affected $19.75 \%$ of the studied elderly population, and a study conducted by (13), who viewed that ear diseases were found in $11.3 \%$ of the studied elderly, and the findings of another study performed by (14) who reported that the frequency of ear diseases among the studied elderly was $5.1 \%$. In a study conducted by (15), only $1.82 \%$ of the studied elderly were affected. On the other hand, a study carried out by (16) revealed that ear diseases accounted for $55.95 \%$ of the studied elderly population. As regards the types of ear diseases among the studied elderly, the current study found diminished hearing as the commonest ear problem among the studied population (37\%) followed by otitis media $(9.4 \%)$ and otitis interna $(2.9 \%)$. These findings are inconsistent with the findings of (1) who reported that the most common ear disease among the studied elderly was aural wax impaction $(48.7 \%)$ followed by age-related hearing loss $(21.4 \%)$ and tinnitus $(10.5 \%)$, and chronic suppurative otitis media was found in $4.6 \%$ of the studied participants. Furthermore, in a study conducted by (16), cerumen impaction was the commonest (30.14\%) presentation followed by otomycosis externa (27.89\%), presbycusis $(24.23 \%)$ and chronic suppurative otitis media (11.11\%), and in a study carried out by (17), chronic suppurative otitis media was the commonest $(25 \%)$ problem, followed by otomycosis externa $(17.5 \%)$ and cerumen impaction (15.3\%). Additionally, another study conducted by (18) found that impacted cerumen was the most frequent ear problem (34.4\%) among the studied elderly followed by hearing loss and otitis externa/media. In a study conducted by (19), the most common ear disease was impacted cerumen $(24.7 \%)$, followed by hearing loss due to old age (Presbycusis) (18.2\%), chronic suppurative otitis media (CSOM) (6.5\%) and Otomycosis (5.4\%). In support of the findings of the current study, another study reported that hearing loss due to old age is the most frequent ear disease among the studied elderly (32.2\%) (3). Hearing impairment was found in $43 \%$ of the participants in a study conducted by (20) and in $82 \%$ of elderly who participated in a study conducted by (21), which is much higher than our findings. In contrast, another study conducted by (22) found that the prevalence of selfreported hearing impairment among the studied elderly was only $6.1 \%$. According to the findings of the current study, no significant association was found between the studied sociodemographic variables and the development of ear infection. These findings are not in line with the results of a study conducted by (2), who reported that there was a significant difference in mean age of onset with gender in cases of otitis media. Another study conducted by (9) revealed that age and educational level were significantly associated with the development of otitis media. On the other hand, another study (23) found that there were no significant differences between both males and females and between different age groups regarding ear problems, which is consistent with our findings. In addition, in another study, (15) found that there were no significant gender differences concerning ear diseases. The study conducted by (12) showed that age significantly affected the occurrence of ear problems among the studied elderly while marital status had no significant effect. The current study revealed that there was no significant association found between smoking status and the development of ear infection which is inconsistent with the findings of (24), who inferred that smoking and passive smoking were among the main risk factors for otitis media. In contrast, (9) reported that smoking had no significant effect on the occurrence of otitis media. None of the studied chronic diseases were significantly associated with ear infections among the studied population, and these findings are not in agreement with the results of the study conducted by (9), as both diabetes and hypertension were found to be significantly associated with the occurrence of otitis media. Regarding the study limitations, we should say that other factors 
which may be associated with the pattern of ear infection were not covered by the current study, focusing on the relation with certain socio-demographic variables, smoking and certain chronic diseases.

\section{Conclusions}

The current study included 183 elderly participants who were referred to or admitted to the hospital during the study period and agreed to participate in the study. The current study revealed that $49.3 \%$ of the participants were suffering from ear disease and 50.7\% were disease-free. Hearing impairment was detected in $37 \%$ of the studied elderly. In addition, $9.4 \%$ and $2.9 \%$ of the participants suffered from otitis media and otitis interna respectively. None of the studied factors had a significant effect on the development and pattern of ear infection among the studied population. Therefore, extension of public health care services to involve the elderly population and deal with the common health problems among them such as ear diseases, which negatively impact their quality of life, is a necessity.

\section{Acknowledgments:}

The authors would like to acknowledge all patients participating in the study and the workers in the hospital for their kind cooperation.

\section{Conflict of Interest:}

There is no conflict of interest to be declared.

Authors' contributions:

All authors contributed to this project and article equally. All authors read and approved the final manuscript.

\section{References:}

1) Kayode AS, Alabi BS, Segun SB, Ogah SA. Audit of otological diseases amongst elderly in Nigeria. Arquivos Internacionais de Otorrinolaringologia. 2010; 14(2): 212-6. doi: 10.7162/S180948722010000200011.

2) Kumari MS, Madhavi J, Meghanadh KR, Jyothy A. A Large Study on Otological Diseases from South India: A Decade Report. J Ear Nose Throat Disord. 2016; 1(1): 1003.

3) Okhakhu A, Okolugbo N, Onyeagwara N. Pattern of otolaryngological disorders amongst geriatric population in Benin City, Nigeria. Int J Mod Altern Med Res. 2013: 14-9.

4) Dillin A, Gottschling DE, Nyström T. The good and the bad of being connected: the integrons of aging. Current opinion in cell biology. 2014; 26: 107-12. doi: 10.1016/j.ceb.2013.12.003. PMID: 24529252, PMCID: PMC3927154.

5) Ohgami N, Iida M, Yajima I, Tamura H, Ohgami K, Kato M. Hearing impairments caused by genetic and environmental factors. Environ Health Prev Med. 2013; 18(1): 10-5. doi: 10.1007/s12199-012-0300-z. PMID: 22899349, PMCID: PMC3541815.

6) Baguley M, Reid E, McCombe A. Scott-Brown's otorhinolaryngology, Head \& Neck Surgery, 7th ed. 2008; 3539-3545.

7) Kumar H, Seth S. Bacterial and fungal study of 100 cases of chronic suppurative otitis media. J Clin Diagn Res. 2011; 5(6): 1224-7.

8) Zhang Y, Xu M, Zhang J, Zeng L, Wang Y, Zheng QY. Risk factors for chronic and recurrent otitis mediaa meta-analysis. PLoS One. 2014; 9(1): e86397. doi: 10.1371/journal.pone.0086397. PMID: 24466073, PMCID: PMC3900534.

9) Park M, Lee JS, Lee JH, Oh SH, Park MK. Prevalence and risk factors of chronic otitis media: the Korean national health and nutrition examination survey 2010-2012. PloS one. 2015; 10(5): e0125905. doi: 10.1371/journal.pone.0125905. PMID: 25978376, PMCID: PMC4433353.

10) Davanipour Z, Lu NM, Lichtenstein M, Markides KS. Hearing problems in Mexican American elderly. Am J Otol. 2000; 21(2): 168-72. PMID: 10733179.

11) Enrietto JA, Jacobson KM, Baloh RW. Aging effects on auditory and vestibular responses: a longitudinal study. Am J Otolaryngol. 1999; 20(6): 371-8. doi: 10.1016/S0196-0709(99)90076-5. PMID: 10609481.

12) Mrinal R, Beena S, Pratibha G, Pankaj B, Srivastava J, Atul B. Morbidity Status and Its Social Determinants among Elderly Population of Lucknow District, India. Sch J App Med Sci. 2013; 1(6): 75864. 
13) Sehgal RK, Garg R, Anand S, Dhot PS, Singhal P. A study of the morbidity profile of geriatric patients in rural areas of Ghaziabad, Uttar Pradesh. International Journal of Medical Science and Public Health. 2016; 5(2): 176-80. doi: 10.5455/ijmsph.2016.0707201535.

14) Shraddha K, Prashantha B, Prakash B. Study on morbidity pattern among elderly in urban population of Mysore, Karnataka, India. Int J Med Biomed Res. 2012; 1(3): 215-23. doi: 10.14194/ijmbr.139.

15) Khan MA, Mushtaq M, Ahmad MZ, Amir H, Bajwa TM, Laeeque SM. Prevalence of geriatric diseases among parents of medical doctors in Lahore. J Ayub Med Coll Abbottabad. 2012; 24(2): 133-5. PMID: 24397074.

16) Onotai LO, Ureh O. Otological Diseases amongst Elderly Patients in Port Harcourt, Nigeria- A 15 Years Review. Glob J Oto. 2017; 6(2): 555682. doi: 10.19080/GJO.2017.06.555682.

17) Okoye BC, Onotai LO. Pattern of geriatric otolaryngological diseases in Port Harcourt. Niger J Med. 2007; 16(3): 239-41. PMID: 17937161.

18) Ologe FE, Segun-Busari S, Abdulraheem IS, Afolabi AO. Ear diseases in elderly hospital patients in Nigeria. J Gerontol A Biol Sci Med Sci. 2005; 60(3): 404-6. doi: 10.1093/gerona/60.3.404. PMID: 15860483.

19) Afolabi O, Ijaduola G. Pattern of ear diseases among older people. East and Central African Journal of Surgery. 2008; 13(2): 96-100.

20) Rahman MW, Ahasan AI, Debnath TK, Jamil ANM, Barua R, Amin MN. Study on Hearing Status of Elderly Patients attending a Specialized ENT Hospital (SAHIC). Bangladesh Journal of Otorhinolaryngology. 2016; 21(2): 80-4. doi: 10.3329/bjo.v21i2.27644.

21) Olaosun AO, Ogundiran O, Tobih JE. Hearing Loss among Elderly Patients in an Ear Clinic in Nigeria. Advances in Life Science and Technology. 2013; 14: 81-6.

22) Lasisi AO, Abiona $T$, Gureje $O$. The prevalence and correlates of self-reported hearing impairment in the Ibadan Study of Ageing. Trans R Soc Trop Med Hyg. 2010; 104(8): 518-23. doi: 10.1016/j.trstmh.2010.03.009. PMID: 20462622, PMCID: PMC2904808.

23) Mishra V, Chakrvarty A, Tripathi I. Illness Pattern of Elderly Residing in Old Age Homes of Varanasi. Journal of The Indian Academy of Geriatrics. 2015; 11(2): 53-8.

24) Wang $\mathrm{J}$, Chen $\mathrm{B}, \mathrm{Xu} \mathrm{M}$, $\mathrm{Wu} \mathrm{J}$, Wang $\mathrm{T}$, Zhao $\mathrm{J}$, et al. Etiological factors associated with chronic suppurative otitis media in a population of Han adults in China. Acta Otolaryngol. 2016; 136(10): 1024-8. doi: 10.1080/00016489.2016.1183818. PMID: 27206699. 